\title{
Managerial Discretion: The Relationship Between Investments in R \& D and Performance -Revisited: Case of Tunisian Enterprises
}

\author{
Dorsaf Bentaleb Sfar ${ }^{1}$ \\ ${ }^{1}$ University of Tunisia, Bardo, Tunisia \\ Correspondence: Dorsaf Bentaleb Sfar, University of Tunisia, ISGT, LR11ES02, 2000, Bardo, Tunisia. E-mail: \\ dorsaf_bentaleb@yahoo.fr
}

Received: December 8, 2020

Accepted: January 8, 2021

Online Published: March 15, 2021

doi:10.5430/jms.v12n1p17

URL: https://doi.org/10.5430/jms.v12n1p17

\begin{abstract}
This article proposes a re-reading of the role of $\mathrm{R} \& \mathrm{D}$ investments in the performance equation when a manifestation of an opportunistic inclination on the part of managers occurs. Often, the manager and the owners express different expectations regarding investment choices in R \& D. Although shareholders are looking for performance, the manager sometimes has a tendency to broaden his managerial discretion. The choice of R \& D investments could thus reinforce managerial entrenchment. We will demonstrate the moderation exercised by managerial discretion on the $\mathrm{R} \& \mathrm{D} /$ Performance relationship.

Our empirical validation will be put to examination against the Tunisian context by deploying various tests. We come to grips with the characteristics of the Tunisian context through an empirical study of 75 companies observed over a 7 -year time lapse, i.e. from 2008 to 2014. The explanatory analysis was an opportunity to highlight the existence of a moderation exercised over the main relationship dealt with.
\end{abstract}

Keywords: managerial discretion, investments in R \& D, performance, governance, moderation

\section{Introduction}

Previous research testifies to the strategic aspect of investments in R \& D and their weight in the development of entities. B. Hall (1989) and D. Aboody and B. Lev (2000) consider that investments in R \& D, thanks to the new processes or products that they generate, promote the company's performance. However, a close look at the theory of the agency, through the treatment of managerial opportunism, suggests the alternative of using investments inR \& D in a perspective other than the improvement of corporate performance (M. Jensen, 1993). D. Hirshleifer (1993) discusses the improvement of reputation or the strengthening of visibility in the labor market as a managerial direction facilitated by R \& D. In addition, this particular type of investment, highly specific, complementary to the skills of the manager, will have to value the presence of the latter at the head of the organization and make it costly to replace ihim/hert; it will have to reinforce his / her managerial entrenchment (A. Shleifer and R. Vishny, 1989). In doing so, K. Eisenhardt (1989), M. Jensen and W. Meckling (1976) recognize the possibility of referral to investment decisions in R \& D harmful to the interests of fund holders, sub-optimal, in favor of the usefulness of the manager.

From these considerations, and respectively to an opportunistic inclination, a mobilization of resources within the framework of the R \& D orientations could not be carried out in the direction of the performance or even the creation of value. In fact, investments in $\mathrm{R} \& \mathrm{D}$ can lead to the extension of managerial latitude in the absence of a relevant control (Jensen, 1993). In this context, It should be remembered that the notion of latitude corresponds to the room for maneuver available to the manager in his decision-making process and in relation to investment choices. So, from a discretionary point of view, the manager will have to act, by setting up R \& D activities, to the detriment of the shareholders in order to consolidate his position within the organization. However, with respect to the theory of stewardship, the managerial latitude must not be restricted but, on the contrary, be extended A discretionary space is fundamental for the manager to be able to achieve fulfillment in the management of his organization (L. Donaldson and J.H. Davis, 1994). In this sense, R. Castanias and C. Helfat (1991) consider that managerial entrenchment is necessarily detrimental to the performance of organizations. As a result, the use of R \& D investments in a logic of entrenchment can only promote value creation. This mixed attitude towards the nature of the influence of $\mathrm{R} \& \mathrm{D}$ investment on performance in the presence of a discretionary inclination pushes us to respond to the following question: to what extent can managerial discretion have effects on the relationship between investment in R \& $\mathrm{D}$ and 
the performance of the company? Our research has two basic objectives. The first is to provide a theoretical perspective on the above-stated relationship. The second is to provide some answers to the question of the existence of links between managerial discretion and the R \& D / Performance relationship in the context of the treatment of the Tunisian context. Several reasons lead us to the analysis of the Tunisian framework. First, this last decade has been characterized by the extent of orientations towards the implications of investment in R \& D (M.Nekhili and E. Poincelot, 2000; C. Djama, G. Dumas and I. Martinez, 2014, R. Guidara and Y. Boujelbene, 2014). However, the various studies carried out have dealt with the context of developed countries because of their sustained commitment to technological innovation and development activities. However, the context of globalization has forced the accession of emerging countries in this perspective of $\mathrm{R} \& \mathrm{D}$. As a result, they are committed to continuous innovation to win the challenge of global competitiveness. In this sense, Chen et al (2005) stress the need for investment efforts in R \& D in developing countries.Consequently, the understanding of the Tunisian national context aims at enriching the research and development perspective and guarantees an original empirical positioning in relation to the various previous research works. Then, Tunisia undertook more and more sustained efforts towards improving its competitiveness in order to join the ranks of the developed countries. The vast program of upgrading its productive apparatus initiated in 1996 testifies to this. This program aims at assisting national entities in their integration into a global economy. In a more recent perspective, the Horizon 2020 program, in which Tunisia participates as an associated country, promotes better access to opportunities for the ecosystem of research and innovation ecosystem in the same way as the associated countries or even as the Member States. of the European Union. In this respect, particular guidelines have been addressed to research and development activities. Some incentives have been implemented. We can mention the investment premium in R \& D (PIRD), national research and innovation program (PNRI) or the incentive scheme for innovation in the field of information technology (RITI). . This is how changes in certain indicators, including internal $\mathrm{R} \& \mathrm{D}$ expenditure (GERD) have been shown. In fact, the GERD, indicators of production and exploitation of knowledge, has shown a change in relation to GDP from $0.45 \%$ to $1.25 \%$ from 2000 to 2009 .

These different guidelines can only reinforce our attention with respect to the role played by R \& D investments in the fine-tuning of managerial behavior in the context of an emerging country that has experienced the jasmine revolution. In this context, it is worth reminding that from 2011, Tunisia has managed to set up a program to fight against corruption. It has redesigned the investment code by setting up a new one whose entry into force was in 2017, presenting a new mode of governance of investments. Within the broader framework of development and structural adjustment policies, the financial sector reform has been one of the steps towards improving the quality of the business environment and its level of competitiveness in the field of finance.at the international level. It is thus wise to position oneself with regard to managerial discretion in the context of the treatment of a particular context and in relation to the nature of the $\mathrm{R} \& \mathrm{D} /$ Performance relationship.To start with, the article calls to mind the research work carried out on the link between managerial discretion and the R \& D / Performance relationship. Then we put forward our research hypotheses as well as the methodological framework of the study conducted on the Tunisian context. The results and the synthesis of the empirical findings will be the subject of the last part.

\section{Theoretical Framework of the Moderation Carried out by Managerial Discretion on the Relationship Between Performance and Investment in R \& D}

This part aims at fine-tuning the nature of the link between managerial discretion and the relationship between performance and investment in R \& D. A review will be proposed in order to explain the importance of managerial discretion.

Investment in R \& D pillar of managerial activism

Traditionally, agency theory provides a very interesting field. It presents the specificity of the relationship between owners and managers. According to this theory, the divergence of objectives between these two actors is a difference in the perception of risks. The former are risk-averse while the latter are risk lovers (O. Williamson 1981, L. Donaldson 1990, J. Barney and W. Hesterly 1996). It thus proposes certain prospecting mechanisms that may reduce the scope of conflicts of interest and reduce managerial discretion (R. Wiseman and L. Gomez-Mejia, 1998, R.. Hoskisson et al, 2000, $\mathrm{H}$. Wu, 2008). However, the mere use of this theory does not provide a comprehensive framework. The orientation towards a theory called entrenchment widened this restricted framework and sometimes encourages to contradict what has already been advanced. Moreover, this theory assumes the insufficiency of the mechanisms with regard to managerial control. These mechanisms initially designed for control can be transformed into entrenchment mechanisms (H. Alexandre and M. Paquerot, 2000; D. Elouadi, 2016). Entrenchment explains the manager's desire to free himself, at least in part, from the control of the fund holders, to increase the dependence of 
the organizational partners on the resources he holds and to be able to obtain considerable personal privileges (B. Pigé, 1998). In this vein, the manager, in keeping with his focus on maximizing the profitability of investments and the administrative capacity he engages, seeks to make himself useful to shareholders (A. Shleifer and R. Vishny 1989). Relational networks, the manipulation of information and specific investments are all determinants of managerial activism (M.Paquerot, 1996). Research and development is thus classified as a low-profile and specific investment favoring managerial entrenchment (A. Shleifer and R. Vishny, 1994).

Invisible investments are essentially based on the private manipulation of information; their profitability depends on the specific information retained and controlled (A. Shleifer and R. Vishny, 1994). Consequently, in order to divert the competing management teams present on the managerial markets, it is a question of investing in low visibility activities, mainly research and development activities. For G. Stigliz and A. Edlin (1992), even if this policy leads to a destruction of value, the annuities incurred as well as their appropriation depend on the visibility of the assets generated.With regard to specific investments, entrenchment is developed through the implementation by managers, of activities for which they have competitive advantages over other competing management teams (internally or externally) (A. Shleifer and R. Vishny, 1994). They thus reduce the risk for managers of being replaced, obtain more wealth in cash or benefits in kind, and increase the managers'"decision latitude"; "The" specific "or" idiosyncratic "investment is the one that results in the loss of value of the assets by the shareholders in case of replacement of its holder" (D .Bentaleb, 2016).

It turns out thus that investment in $\mathrm{R} \& \mathrm{D}$ as a specific investment is built by the appropriation of the manager's particular skills in the context of an internal environment represented by the company. As a result, a chief executive may choose investments that have a strong complementarity with managerial skills or investments that are more complex and less understandable by competing management teams, which reduces the risk of his replacement (Paquerot, 2008). Investment in R \& D, through a desire to capitalize key skills of its initiator, suggests a specific pillar imposing its mandatory presence at the head of the project (O. Williamson, 1988) which promotes its entrenchment or its activism ( A. Shleifer and R. Vishny, 1994). A manager is said to be active if he has to engage in manipulative orientations, privileging his own interests at the expense of the shareholders thanks to a logic of valorization of skills and managerial capital (G .Charreaux, 2015).Thus, we believe that investment in R \& D is turning away from its main purpose- from a strategic orientation in favor of performance (C. Hill et al., 2000) towards a determinant of managerial activism (M.Paquerot, 1996). Indeed, S. Ume and A. Hussein (2018) consider that $\mathrm{R} \& \mathrm{D}$ activities stimulate productivity, the development of business opportunities and increased consumer utility. They represent the heart of technological innovation. However, A. Shleifer and R. Vishny (1994) focus on this particular means as a vector of managerial activism. We thus seek to position ourselves in relation to the R \& D and performance relationship in the presence of the discretionary managerial variable.

The term R \& D covers three activities (Note1): basic research (expressed in terms of work undertaken to acquire new knowledge), applied research (practice-oriented) and experimental development (directed towards the conceptualization and implementation of new products), new processes, etc.) R \& D relationship and performance; Evolution according to the aspirations and level of managerial discretion. Discretionary latitude or discretionary space can be defined as "the space left for individual judgment and choice" (A. Carroll, 1979). From a corporate governance perspective, it refers to the part of managerial power that escapes shareholder control (D .Bentaleb, 2014). In a logic of managerial activism, we can indicate that this part evolves according to the personal aspirations of the manager and its progression in its process of entrenchment. M.Paquerot (1996) describes the manager's transition in his entrenchment through three main phases; a recovery phase, the reduction of the means of control and the increase in consumption. It explains the change in the link between investments in R \& D and performance according to the extent of the managerial discretion developed.

In a first phase of valuation, usually characterized by a very delicate position, minimal power, little room for maneuver, little knowledge specific to the firm, the newly installed manager is perfectly replaceable. He will have to undergo, more often, a rather attentive and intensified control. The achievement of a good performance on his part under the constraint of minimizing the risk and the valuation of skills acquired will have to build the confidence of the other organizational partners towards him. The first decisions made by the latter will be subject to observation and control which does not allow them to undertake opportunistic investments whose profitability is uncontrolled. As a result, he will avoid major changes and opt for profitable investments that will increase the wealth of other members of the company in the short term. As a result, the trend is towards increasing power, creating investor dependence on it in favor of minimizing the inspection force. In addition, he will begin to build relational networks, informal contracts most often followed by some control of the informational 'nuts and bolts'. Thus, for the partners of the company, this phase may seem "seductive" allowing them to collect "additional remuneration" capable of 
making them be paid dearly. We believe that the level of discretion, non-existent or even weak, is not likely to influence the relationship between investment in R \& D and performance. All orientations are towards the creation of additional annuity for the shareholders holding the fund. The R \& D perspective is rather in the sense of survival within the entity. The manager will have to reinforce his roots and guarantee his continued position in the company in question (R. Castanias and C. Helfat, 1992, G. Garvey and P. Swan, 1994).By gaining autonomy and a certain satisfactory level of authority, he will have to progress to reach his second phase, translated by a reduction of the means of control. Thanks to the power obtained and because of his superior performance, the manager can move towards investments that do not optimize the created value, but rather go in the direction of the increase of information asymmetry or the "deterrence" of competing managers. The close relationship between the business activity and the specific skills of managers is, at this level, fundamental. In this sense, executives are led to undertake implicit contracts, opt for the growth of the firm or change the structure of the company ... Resorting to a change in the structure of their shareholders by diluting for example the majority shareholders is one of the possible strategies for increasing information asymmetry. It can even, in the same way, seek other partners more loyal towards him. In this phase, the managers will have greater freedom of action and will be able to increase their consumption without the partners being able to oppose it. They will have more autonomy and guarantee the widening of their discretionary spaces. The managerial inclinations for R \& D investments will have to privilege the amplification of the power over the actors holding the capital. We believe that the level of discretion is likely to affect the R \& D / performance relationship. The tendencygoes thus towards a satisfaction of the personal aspirations and those of the fund holders. The underlying assumption is that managers are supposed to keep their place as long as they provide capital holders with a minimum return (R. Castanias and C. Helfat, 1992, G. Garvey and P. Swan, 1994). In contrast to A Shleifer and R. Vishny (1986), the specific knowledge of executives provides annuities that benefit both the firm, the shareholders and themselves. Once they succeed in reducing the possible inspection outcomes engaged by the fund holders, we can confirm the shift towards the phase of maturity still called phase of increase of consumption, i.e. the third phase of entrenchment. Thus, following the change in the structure of their environment, managers can increase their remuneration or benefits in kind. The emergence of opportunistic behavior thus surfaces. Managers take advantage of the advantages granted by their positions and the possible relations woven with the various organizational actors, whether internal or external.

Having built a "reputation" (Paquerot, 1996), invested in specific assets and promoted information retention (A. Shleifer and R. Vishny, 1989, R. Morck et al, 1990), the manager can also combine the functions of CEO and director (S. Finkelstein and R. D'aveni, 1994, M. Paquerot, 1997) and gain legitimacy with the directors by appointing for example internal directors (B. Hermalin and M. Weisbach, 1988) or by rallying outside directors to his cause. At this level, the managers can be opportunistic and take advantage of the advantages granted by their positions and the possible relations woven with the different actors, both internal and external.It must be remembered that opportunism, "is characterized by any attitude to disclose distorted information on the market and omit the transmission of important data for the conclusion of a contract" (Narayanan, 1985). It implies the valuation of self-interest, of any effort calculated to deceive, manipulate, conceal, omit or mislead (F. Frery, 2008). We also note that the risk of opportunism is all the greater as the amount of investments to be made and the expected benefits are high. For L. Donaldson (1995), the opportunistic inclination of individuals, a central element of transaction cost theory, can be described as "anti-managerial".Normally, the entities in charge of control and enforcement of sanctions are unable to perform their duties given the outrageous cost that can be triggered following such an operation. In addition, they can make investments that do not maximize the value created, but rather that ensure the increase of information asymmetry or the development of a certain complementarity between the activity of the company and their specific skills. By doing so, the manager increases his autonomy, his discretionary space and possibly his consumption at the expense of the overall performance of the firm. For J. Pfeffer (1981), the entrenchment theory is to some extent related to the argument of the theory of dependence on resources, according to which power belongs to the actors who provide an indispensable resource for the functioning of the resource organization and which are not easily replaceable. Managers who seek entrenchment, have an interest, as well, not to depend on contributors of external resources on the one hand, and to "represent themselves a factor of production difficult to substitute", on the other hand. We thus make our basic assumption that discretion is able to adversely affect the R \& D / performance relationship. The regulation of this relationship is a function of the managerial life cycle in its process of activism. In this way, we presume the empirical demonstration of a moderating effect on the main relation dealt with. In this same framework of analysis, it should be noted that the logic of description of managerial discretion throughout our development defends the damaging postulate of A.Shleifer and R.W. Vishny (1986). It allows part of the control of the shareholders by subordinating profitability to their presence. By developing the investments that are specific to them, they reduce competition in the labor market by reducing the 
number of competing teams capable of managing the firm without maximizing shareholder wealth and giving free rein to opportunism. Entrenchment is thus represented by the development of idiosyncratic investments, the manipulation of information as well as the control of resources. The major orientation adopted by the manager is to represent his position as a factor that is difficult to replace. It seems interesting to us to raise the contradictory reflection. R. Castanias and C. Helfat (1992) as well as G. Garvey and P. Swan (1994), on the contrary think that the realization by the managers of investments which are specific to them and which they are therefore able to better manage than the other assets of the firm, allows them to generate annuities that they would not have created otherwise. In this context, the company will be their space of creativity and innovation that can materialize their belonging and their cohesion with the other stakeholders of the organization. As a result, investors and other partners of the firm benefit indirectly from entrenchment. Managers are expected to keep their job as long as they provide capital holders with a minimum return. In contrast to A.Shleifer and R. Vishny (1986), the specific knowledge of managers is a source of annuities that benefits the firm, the shareholders and themselves alike.

This work will allow us to position ourselves in relation to one of our theoretical predictions; discretion harmful or beneficial to the entity.

\section{Empirical Study}

This research is ambitious in so far that it purports to examine the influence of managerial discretion on the nature of the relationship between $\mathrm{R} \& \mathrm{D}$ and the performance of the company.

\subsection{Presentation of the Sample}

A look at the breakdown displayed by the Agency for the Promotion of Industry and Innovation in Tunisia, now the APII, of R \& D expenditure by sector between the period 2008 and 2014 shows a fairly high percentage of investments made in the following seven sectors compared to other activity sectors:

- Electrical, Electronics and Household Appliances Industry (IEEE)

- The food and agri-business industry, (IAA)

- Mechanical and Metallurgical Industry (IMM)

- The chemical industry (ICH)

- The textile and clothing industry (ITH)

- The Ceramic and Glass Building Materials Industry (IMCC)

- Information and Communication Technology (ICT)

Thus, we have considered the companies belonging to these different sectors in the constitution of our sample. Enterprises belonging to the financial sector were not taken into consideration due to the lack of an atypical structure. As a result, we used data provided by APII and annual reports.However, due to lack of availability of information, some companies were taken out to only keep a group of 75 companies observed over a seven-year period of time i.e.from 2008 to 2014. It is worth recalling, in this framework of analysis, that it would be interesting in the analysis of the Tunisian framework, an emerging country context, to contextualize the sectorial classification. Nieto et al (2005), consider that the understanding of the context of emerging countries requires a positioning in relation to the most intensive intangible sectors. For S. Boujelben (2010), the treatment of the traditional sector classification "high technology" vs. "traditional" for emerging countries no longer holds true as the high-tech sector in Tunisia is not very developed. Thus, we will have to refer to the national data on $\mathrm{R} \& \mathrm{D}$ expenditure incurred by Tunisian companies (Note 2). It is worth noting in this context that we have considered the ISO 9001 version 2000 certification as a selection criterion since it will allow us to guarantee the establishment of an R \& D laboratory (Note 3).

The Sectoral breakdown of the sample is as follows:

Table 1. Breakdown of the sample by sector of activity

\begin{tabular}{lllc}
\hline Sectors & \multicolumn{1}{l}{$\begin{array}{l}\text { Number of } \\
\text { companies }\end{array}$} & Pourcentage \\
\hline The Agri-business Industry (IAA) & 10 & 13.33 \\
Electrical, electronicsindustry (IEEE) & 12 & 16
\end{tabular}




\begin{tabular}{lll} 
Mechanical and metallurgical industry (IMM) & 8 & 10.67 \\
ChemicalIndustry (ICH) & 11 & 14.67 \\
Textile \&ClothingIndustry(ITH) & 12 & 16 \\
Ceramics, Glass and Building materials Industry (IMCC) & 8 & 10.67 \\
Information and Communication Technology (ICT) & 14 & 18.66 \\
\hline Total & 75 & $100 \%$ \\
\hline
\end{tabular}

\subsection{Presentation of the Used Variables}

Within this framework, we have cross-referenced the managerial discretion and relationship performance / R \& D investments in order to position ourselves with regard to the theoretical predictions. We consider, in this way, discretion as a moderating variable, performance as a dependent variable, and $\mathrm{R} \& \mathrm{D}$ as an independent variable.

Performance, R \& D and control variables measurement

- Research and Development (RDEV): Represents the intensity of investments in research and development. It is measured by total research and development expenditures divided by total assets (I.Khanchel 2005, J. Di Vito, C. Laurin, and Y. Bozec 2008, B. Mezghanni 2011).

- Performance (PRF): represents the future performance of the organization calculated through the average value of operating performance of the last five consecutive years. It is represented by the ratio: Operating income before depreciation and expenditure on research and development / total sales (Aboody and Lev, 2001, Ding et al, 2007, Yang et al, 2007 and B. Mezghanni, 2011).

The choice of five years is justified by the guidelines according to which "the useful life of $R \& D$ capital varies from five to nine years" B. Sellami (2010). It is thus detrimental to consider the five-year period for assessing the impact of R \& D strategies (B. Lin and J. Chen, 2005).

- Level of indebtedness (END): is apprehended through the ratio between total debts and total assets. It is bound to act positively on the performance of the company (S. Nickell et al, 1997). Indeed, availability of cash flow can encourage managers to engage in the prospect of maximizing personal income to the detriment of fund holders (Jensen, 1986).

- Size of the business (TAIL): represented by the logarithm of the total assets of the firm. R \& D is generally targeted by large firms (G.Hansen and C.Hill, 1991).

The commitment of companies to costly projects through the availability of resources is likely to boost the performance of the entity (Morck et al, 1988).

- Sector effect (SEC): The sector to which the company belongs could be decisive for the level of performance (D. Bentaleb, 2018). Considering this variable will allow us to isolate the sector effect with respect to the error term. They are dummy variables: IAA, IEE, IMM, ITH, IMCC, ICT ICH, take the value 1 if the company belongs respectively to the sector of activity (the agri-business industry, Electrical, electronics and home appliances industry, Mechanical and Metallurgical industry, Textile and Clothing industry, Building Materials for Ceramics and Glass, Information and Communications Technology, Chemical Industry.

- Age of the firm (AGEFIRM): Di Vito et al (2008) consider the determining character of the age of the firm as to the improvement of the performance. Moreover, the level of performance varies according to the life cycle of the organization. We thus consider the logarithm of the number of years of existence of the company.

- YEAR:dummy variables: AN01: 1 if the year of observation is 2008, and 0 otherwise; AN02: 1 if the year of observation is 2009, and 0 if not ... . This introduction of year variable will allow the control of time given the changes in performance from one year to another depending on environmental changes and economic conditions (Katila and Ahuja, 2002).

Measurement of managerial discretion

Most of the previous studies dealing with managerial discretion make use of proxy variables such as the composition of the board of directors, seniority in the position, or even the capital structure (E. Ruiz-Barbadillo, E. Biedma-López, N. Gómez-Aguilar, 2007).

We adopt in this context the following variables: 
- The age of the manager (AGE): Reflects his relational network, his experience and the understanding of his managerial latitude. The older the manager, the higher the level of discretion (Paquerot, 1996, P. Stamford, 1998, 2000, E. Dedman, 2000, H.Gharbi, 2005, D. Bentaleb, 2014, 2016).

According to the analyzes of A. Shleifer and R.Vishny (1994) as well as those of R. Morck et al (1990), beyond a certain age, the manager will have to appropriate annuities beyond what is provided by the contractual relationship. The tendency is towards a valuation of his own interests at the expense of those of the holders of capital. Registration is thus in the negative logic of managerial discretion.Contrary to this rationale and in the framework of the positive sense, R. Castanias and C. Helfat (1991) consider that a managerial discretion is to be reinforced in order to guarantee managerial development. By referring to the theory of stewardship, the shareholders "have an interest in giving a certain room of maneuver to the non-opportunistic managers, giving primacy to the general interest so that they can contribute to the long-term development of the enterprise while serving the general interest (L. Donaldson and JH Davis, 1994). Managerial latitude should not be systematically reduced, but on the contrary extended. The role of the control mechanisms is then reduced in order to privilege the development of the discretionary space of the manager considered to be vital for the creation of the partnership value. The widening of the discretionary space of the managers, viewed in this light, is not necessarily detrimental to the performance ". (D.Bentaleb, 2014).As a result, the manager's age is synonymous with expertise and a portfolio of relationships. The older he is, the more experience he has, the more likely he is to develop a portfolio of strategic relationships with the various organizational stakeholders (C. Pochet C, 1998). Age is able to positively impact the relationship between business performance and $\mathrm{R} \& \mathrm{D}$ investments.

- We will attempt to verify the following hypothesis:

H1: The manager's age may have a negative impact on the relationship between investments in R\&D.

- The length of the position of the manager or his seniority at his post (ANC)

Represents seniority in the position of manager/ or on the board, is an indicator of managerial expertise and his ability to negotiate with different organizational partners. The older the manager is, the more he will have to widen his discretionary space which privileges his activism (NL Rose and A. Shepard, 1997, B. Pige, 1998, E. Dedman, 2000, H. Gharbi, 2008, D Bentaleb, 2014, 2016).We believe, in the same way, that linking managerial discretion with $\mathrm{R} \& \mathrm{D}$ investments and performance is a function of the duration of the term. At the beginning of his commitment, the manager will have to make himself look more valuable with the shareholders. He will have to build a good reputation. The search for performance will be one of the most imminent prerogatives. However, as he advances in his career, the older the manager, the more he will have to grab annuities beyond what is procured by the contractual relationship. Seniority is synonymous with relationship network development with the different organizational partners. He will have to dodge shareholder control in favor of an attachment of the latter to him. In this framework, P. Stamford (2000) defends the hypothesis of the reduction of the "continuum of expected future annuities" with the increase of his seniority. The manager will be less concerned about the development of his reputation and will be less inclined to incentive schemes. In keeping with the work of Y.W. Yang et al (2007), thus predicting a negative influence between managerial discretion and the relationship between $\mathrm{R} \& \mathrm{D}$ investments and performance. The market reacts negatively to the maintenance of investments in $\mathrm{R} \& \mathrm{D}$ with the increase of the seniority of the manager in position (B. Sallami, 2010)

H 2: The seniority of the manager may have a negative effect on the relationship between the organization's performance and the investments in R \& D.

\subsection{The Models Used}

In this work, we will insist that managerial discretion has a negative influence on the nature of the relationship between R \& D investments and the company's performance. To measure this influence we will have to resort to a moderation analysis. The test of the moderating effect of managerial discretion on the relationship between performance and the use of $\mathrm{R} \& \mathrm{D}$ investments will be made through the use of the guidelines of Baron and Kenny (1986). A variable is called a moderator if it moderates the direction and / or the strength of the effect of the exogenous variable $X$ on the endogenous variable $Y$ (Baron and Kenny, 1986).There are three approaches to analysis: The influence of $\mathrm{X}$ on $\mathrm{Y}$; The influence of $\mathrm{Z}$ on $\mathrm{Y}$. The influence of the interaction of $\mathrm{X}$ and $\mathrm{Z}$ on $\mathrm{Y}$. Moderation is observed when the influence of the interaction is significant; it is not necessary for the first two links to be so.

We then propose the following regression model test: 
PERFi, $\mathrm{t}+1 \rightarrow \mathrm{t}+5=\beta 0+\beta 1 \mathrm{RDit}+\Sigma \beta 1+\mathrm{h} \mathrm{X} \mathrm{hit}+\Sigma \beta 3+\mathrm{h}$ RDit $* \mathrm{X}$ hit $+\beta 7$ ENDETit $+\beta 8$ SIZE +

$$
\beta 9 A G E i, \mathrm{t}+\Sigma \beta 10 \text { SECTEURi, } \mathrm{t}+\Sigma \beta 11 \text { ANNEEi, } \mathrm{t}+\varepsilon \mathrm{i}, \mathrm{t}
$$

$\mathrm{X}$ : variables related to managerial discretion (AGE and ANC)

The overall regression model including all interaction variables is as follows.

- Model 1: PERFi, $\mathrm{t}+1 \rightarrow \mathrm{t}+5=\beta 0+\beta 1$ RDit $+\beta 2$ AGEit $+\beta 3$ RDit $*$ AGEit $+\beta 4$ ENDi, $\mathrm{t}-1+\beta 5$ TAILi, $\mathrm{t}-+$ $\beta 6$ AGEFIRMi, $\mathrm{t}-1+\Sigma \beta 7 \mathrm{SECi}, \mathrm{t}+\Sigma \beta 8$ ANNEEi, $\mathrm{t}+\varepsilon \mathrm{i}, \mathrm{t}$

- Model 2: PERFi, $t+1 \rightarrow \mathrm{t}+5=\beta 0+\beta 1$ RDit $+\beta 2$ ANCit $+\beta 3$ RDit $*$ ANCit $+\beta 4$ ENDi, $t-1+\beta 5$ TAILi, $t-+$ $\beta 6$ AGEFIRMi, $\mathrm{t}-1+\Sigma \beta 7 \mathrm{SECi}, \mathrm{t}+\Sigma \beta 8$ ANNEEi $\mathrm{t}+\varepsilon \mathrm{i}, \mathrm{t}$;

It should be noted that all explanatory variables were delayed by one year compared to the explained variable ((Lundstrum, 2002, Chen et al, 2008, Chen and Hsu, 2009, B. Sellami, 2010) in order to be able to overcome the risk of reverse causality (Lee and Park, 2008) and to give precedence to the impact of managers in strategic choices (Chen and Hsu, 2009).

\subsection{The Results}

In this section we deal with descriptive analyzes, multivariate tests and then finish with the analysis of the moderation exerted by managerial discretion on the nature of the relationship between $\mathrm{R} \& \mathrm{D}$ investments and the performance of Tunisian companies.

\subsubsection{Descriptive Statistics}

Table 2 represents the descriptive statistics of the different variables used in this framework.

Table 2. Descriptive statistics

\begin{tabular}{|c|c|c|c|c|c|}
\hline Variables & $\begin{array}{l}\text { Numberof } \\
\text { observations }\end{array}$ & Average & $\begin{array}{l}\text { Standard } \\
\text { deviation }\end{array}$ & Min & Max \\
\hline PERF & & 11.91 & 7.53 & -1.76 & 25.48 \\
\hline $\mathrm{RD}$ & & 4.24 & 4.43 & 0.04 & 22.15 \\
\hline AGE & & 54.22 & 7.8 & 39 & 78 \\
\hline ANC & & 9.72 & 7.6 & 0 & 35 \\
\hline END & & 0.27 & 0.69 & -0.17 & 15.46 \\
\hline TAIL & & 0.12 & .656 & -0.18 & 16.41 \\
\hline AGEFIRM & & 15.62 & 1.78 & 11.63 & 25.16 \\
\hline
\end{tabular}

This table presents the descriptive statistics of the variables used in the analysis. PERF: the average of the operating performance ratios of the five consecutive years. R \& D represents the ratio of total R \& D spending to turnover. AGE indicates the age of the manager. END is the ratio of debts to total assets. AGEFIRM age of the firm. TAIL is logarithm of total staff

The average of future performance achieved is about 11.91. The average operating performance ratio for the five consecutive years ranges from a low of -1.76 to a high of 25.48 . The average $\mathrm{R} \& \mathrm{D}$ expenditure is 4.27 as a percentage of sales. The average age of the managers is about 55 with an average 10-year seniority at the position.

\subsubsection{Verification of the Absence of Multicollinearity}

The analysis of the correlation matrix shows that there is no problem of multicollinearity. Indeed, all the correlation coefficients are less than 0.8 . The absence of multicollinearity and the low correlation between pairs of variables avoids the generation of bias. In this respect, we assume that the heterogeneity of the sample is taken into account in order to rule on the moderation exercised by managerial discretion. 
Table 3. Pearson Correlation Matrix

\begin{tabular}{lcccccc}
\hline & PERF & AGE & ANC & END & TAIL & AGEFIRM \\
\hline PERF & 1 & & & & & \\
AGE & 0.0208 & 1 & & & & \\
ANC & 0.0242 & -0.132 & 1 & & & \\
END & 0.0502 & 0.0313 & -0.044 & 1 & 1 & \\
TAIL & 0.0562 & 0.2086 & 0.0368 & 0.0621 & 0.0833 & 1 \\
AGEFIRM & 0.0603 & 0.0216 & 0.0744 & 0.0414 & \\
\hline
\end{tabular}

This table presents the Pearson Correlation Matrix of the variables used in the analysis. PERF: the average of the operating performance ratios of the five consecutive years. $\mathrm{R} \& \mathrm{D}$ represents the ratio of total $\mathrm{R} \& \mathrm{D}$ spending to turnover. AGE indicates the age of the manager. END is the ratio of debts to total assets. AGEFIRM age of the firm. TAIL is logarithm of total staff

\subsubsection{Specification, Heteroscedasticity and Autocorrelation Tests}

The analysis concerns a sample of 75 Tunisian companies observed over a 7-year time axis from 2008. The use of the panel data structure requires us to follow a certain number of steps:

- Eliminate the use of a fixed-effect model following the introduction of invariable dummy variables in time.

- Perform the following tests:

- The "Breusch-Pagan Lagrangian Multiplier test for random effects" test allowing the identification of individual effects and will make it possible to decide on the type of model to be retained; "The pooled" or the "random effect" model

-"Breusch-Pagan" Heteroskedasticity Test

- Wooldridge autocorrelation test allows testing the autocorrelation of errors;

Table 4. Breusch-Pasan Lasransian multiplier test for random effects

\begin{tabular}{lll}
\hline & Model 1 & Model 3 \\
\hline chi2 $(1)=425.6$ & Chi2 $(1)=522.75$ \\
& \\
\hline Prob > chi2 $=0.000$ & Prob > chi2 $=0.000$ &
\end{tabular}

The result of the "Breusch-Pagan Lagrangian Multiplier test" test confirms the existence of individual effects (significant chi-square statistic, Prob> chi2 $=0.000$ ). The appeal is thus in favor of the random effect model.

Table 5. Heteroscedasticity Test

\begin{tabular}{ll}
\hline Model 1 & Model 2 \\
\hline $\mathrm{F}=4312.83$ & $\mathrm{~F}=1243.28$ \\
\hline Prob $>\mathrm{F}=0.000$ & Prob $>\mathrm{F}=0.000$ \\
\hline
\end{tabular}

Table 5 confirms the heteroscedasticity problem, Fisher statistic $F$ which is significant (pob $>F=0.000$ ). 
Table 6. Wooldridgeautocorrelation Test

\begin{tabular}{ll}
\hline Model 1 & Model 2 \\
\hline $\mathrm{F}(1,103)=2.078$ & $\mathrm{~F}(1,103)=2.082$ \\
\hline Prob $>\mathrm{F}=0.1522$ & Prob $>\mathrm{F}=0.1505$ \\
\hline
\end{tabular}

The intra-individual autocorrelation test confirms the absence of serial autocorrelation (Prob> F> 0.05).

The result of this series of analyzes is the absence of the problem of autocorrelation and the existence of a problem of heteroscedasticity, which prompts us to use the least squares method.

\subsubsection{Results of Regressions}

The results of the regressions relating to the study of moderation exercised by managerial discretion are as follows:

Table 7. The FGLS regression results

\begin{tabular}{|c|c|c|}
\hline \multicolumn{3}{|l|}{ Cross-sectional time-series FGLS regression } \\
\hline Coefficients: Generalized Least Squares & Panels: heteroskedastic & Correlation: no autocorrelation \\
\hline Number of obs $=525$ & Number of groups $=75$ & Time periods $=7$ \\
\hline \multicolumn{3}{|l|}{ Variable to explain: PERF } \\
\hline Explanatory variable & Model 1 & Model 2 \\
\hline \multirow[t]{2}{*}{ Constant } & 10.0842 & 8.032 \\
\hline & $(4.56)^{* * *}$ & $(7.68) * * *$ \\
\hline \multirow[t]{2}{*}{$R D$} & 1.325 & 0.436 \\
\hline & $(5.48)^{* * *}$ & $(0.48)$ \\
\hline \multirow[t]{2}{*}{$A G E$} & 0.1543 & \\
\hline & $(5.62)^{* * *}$ & \\
\hline \multirow[t]{2}{*}{$R D * \mathrm{AGE}$} & 0.234 & \\
\hline & $(2.52)^{* * *}$ & \\
\hline \multirow[t]{2}{*}{$A N C$} & & 0.042 \\
\hline & & $(3.72)^{* * *}$ \\
\hline \multirow[t]{2}{*}{$R D^{*} \mathrm{ANC}$} & & 0.532 \\
\hline & & $(1.43)^{* * *}$ \\
\hline \multirow[t]{2}{*}{ END } & 0.964 & 0.439 \\
\hline & $(5.32)^{* * *}$ & $(6.32)^{* * *}$ \\
\hline \multirow[t]{2}{*}{ TAIL } & 0.768 & 0.576 \\
\hline & $(0.43)$ & $(8.67)$ \\
\hline \multirow[t]{2}{*}{ AGEFIRM } & 1.657 & 0.765 \\
\hline & $(0.46)^{* * *}$ & $(5.56)^{* * *}$ \\
\hline SEC (dummies) & yes & yes \\
\hline ANNEE( dummies) & yes & yes \\
\hline Wald chi2 & $564.73 * * *$ & $654.12 * * *$ \\
\hline Prob $>$ chi 2 & 0.000 & 0.000 \\
\hline Log likelihood & -7658.453 & -633.902 \\
\hline
\end{tabular}

*significant at 0.10 level ** significant at 0.05 level ***significant at 0.01 level 
The analysis in Table 7 shows that the interaction effects of the variables of managerial discretion and R \& D investments $(\mathrm{RD} * \mathrm{AGE}$ and $\mathrm{RD} * \mathrm{ANC})$ on the firm's performance are positive and significant at the $1 \%$ level.This goes in the direction of confirming the moderation exerted by managerial discretion on the nature of the relationship between performance and the intensity of $\mathrm{R} \& \mathrm{D}$ investments. This result is consistent with valuing the weight of managerial discretion in improving the entity's performance via $\mathrm{R} \& \mathrm{D}$ investments.Managerial discretion identified as a part of power that escapes shareholder control cannot be perceived as detrimental to corporate performance. The room for maneuver in decision-making is beneficial for the well-being of society. This analysis is part of the continuity of the work carried out on the Tunisian context and showing the significant positive effect of the discretionary power of managers and the accounting performance of Tunisian companies (I. Khanchel, 2009). We are thus within the rationale of stewardship according to which the margin of maneuver left to the manager is able to lead to the long-term development of the company. The primacy of the general interest allows moving towards a broadening of the managerial latitude thanks to the widening of the discretionary space, supposed to becrucial for the passage from the creation of value to the creation of values (L. Donaldson and JH Davis, 1994). Their free hands will allow them to bring to their functions all the intrinsic motivation they naturally possess (Bentaleb, 2014). The expertise held by the manager thanks to his acquired experience and mastery of the informational mechanisms will allow him to influence the organizational success through the various strategic choices he will have to put in place. Indeed, the more seniority the manager has in the position or is older, the more he will have to control the information mechanisms. The managers' cumulative knowledge will facilitate the choice of decisions, particularly in terms of research and development and in favor of the company's performance.

Our results also show that there is a positive relationship existing between indebtedness and corporate performance. We thus confirm the position S. Nickell et al (1997) who consider that debt is bound to reduce the level of managerial discretion and improve the performance of companies. Similarly, large companies can help improve the performance of the organization (Di Vito et al, 2008). The position of Tunisian firms in their life cycle is decisive for their performance. On the other hand, we are not able to rule on the relationship between the size of the firm as measured by means of logarithm of the total assets of the firm and its performance.

\section{Conclusion}

The objective of this research has been to consider the impact of managerial discretion on the performance / investment in R \& Drelationship. To do so, we have reviewed the different theoretical analyzes addressing the link between the variables used. The orientations dealt with, both theoretical and empirical, are the most often opposed.

The harmful logic of the managerial discretion of A.Shleifer and R .W. Vishny (1986) describes its negative influence on the main processed relation; the higher the level of discretion, the lower the impact of R \& D investments on the company's performance. The manager will have to privilege the not very visible and specific investments in order to make himself/ herself irreplaceable in the eyes of the funds holders (M.Paquerot, 1996). On the other hand, R. Castanias and C. Helfat (1991) consider that managerial discretion should be reinforced in order to guarantee managerial gratification. They argue for a widening of the discretionary space of the managers, one that would be innovator and creator of value. The influence of discretion on the performance / investment in R \& D relationship is rather in favor of the shareholders holding capital. Then in a second phase, we have analyzed the moderation applied by managerial discretion in the context of the mobilization of data on Tunisian companies-the Tunisian context of an emerging country that has gone through the jasmine revolution and which, on the one hand, has taken a turn for the fight against all forms of corruption and wants to reinforce R \& D activities, on the other hand. We believe that the free hands of managers will allow them to bring to their functions all the intrinsic motivation that they naturally have to develop the creation of value of any beneficial owner. The issue at stake would be then to know the impact of a possible limitation of the discretionary space of the Tunisian manager and its impacts in terms of opportunity cost.

\section{Limits and Perspectives}

This research work involves an opening of perspectives towards the analysis of the characteristics of investments in $R$ \& D. Indeed, the integration of R \& D investments as such and by themselves represents a means of innovation, but does not in any manner measure innovation. It would thus be interesting to consider integrating the "type of investment" or "type of innovation". It is within this vey context that we suggest to examine moderation as exerted by the managerial skills. These dimensions, being more cognitive, will enable us to analyze the weight of the managerial know-how. Moreover, the close relationship existing between the company's activity and the specific skills of the managers is of utmost importance. The implementation of R \& D investments accounts for the provision of a large part of the value to a degree such as an executive is likely to develop exceptional skills, specific to the 
company itself (Noe and Robello, 1997). Managers can focus on R \& D activities that require their managerial skills and abilities so that, on the one hand they can have a positive impact on the owners' perception of their skills, which increases their value on the labor market (Shleifer and Vishny, 1989), and on the other hand, they are able to avoid the threat of being dismmissed by fund holders (Stigliz and Edlin, 1992). Specific skills are thus able to moderate the link between the intensity of investment in R \& D and managerial discretion (Chen, 2014). However, the non-availability of information on the context of Tunisian companies has prevented us from dealing with all the avenues and prospects that may seem promising for the examination of the subject at hand.

\section{References}

Aboody, D., \& Lev, B. (2000). Information asymmetry, R\&D and insider gains. The Journal of Finance, 55, 2747-2766.

Alexanre, H., \& Paquerot, M. (2000). Efficacité des structures de contrôle et enracinement des dirigeants. Finance Contrôle Stratégie, 3(2), 5-29.

Barney, J., \& Hesterly, W. (1996). Organizational economics: Understanding the relationship between organizations and economic analysis. In S. Clegg, C. Hardy, \& W. R. Nord (Eds.), Handbook of organization studies (pp. 115-147). Thous; Oaks, CA: Sage.

Baron, R. M., \& Kenny, D. A. (1986). The moderator-mediator variable distinction in social psychological research: Conceptual, strategic, and statistical considerations. Journal of Personality; Social Psychology, 51(6), 1173-1182.

Bentaleb, D. (2014). Contrôle des institutionnels et pouvoir discrétionnaire des dirigeants -Cas des entreprises tunisiennes cotées. La Revue des Sciences de Gestion - direction et gestion des entreprises, (265), 69-77.

Bentaleb, D. (2016). Principaux acteurs organisationnels: Quelle action sur l'activisme managérial? Cas des entreprises tunisiennes cotées. AIMS 2016.

Bentaleb, D. (2018). Présence des femmes dans les conseils d'administration et performance des entreprises: étude du cas tunisien. Revue Recherches en Science de Gestion, (127), 33-56.

Carrol, A. B. (1979). A three dimensional model of corporate social responsibility. Academy of Management Review, (4), 497-505.

Castanias, R., \& Helfat, C. (1991). Managerial resources and rents. Journal of Management, (17), 155-171.

Charreaux, G. (2015). Pour une véritable théorie de la latitude managériale et du gouvernement des entreprises. Revue Française de Gestion, 8(253), 189-212.

Chen, H. (2014). Board Capital, CEO Power and R\&D Investment in Electronics Firms. Corporate Governance: An International Review, 22(5), 422-436.

Chen, H. L., \& Hsu, W. T. (2009). Family ownership, board independence and R\&D investment. Family Business Review, 22(4), 347-362.

Chen, H. L., Hsu, W. T., \& Huang, Y. S. (2008). Top management team characteristics, R\&D investment and capital structure in the IT industry. Small Business Economics.

Di Vito, J., Laurin, C., \& Bozec, Y. (2008). Corporate ownership structure and innovation in Canada. Actes du 29ème congrès de l'Association Francophone de Comptabilité, CergyMai 2008.

Ding, Y., Stolowy, H., \& Tenenhaus, M. (2007). R\&D productivity: An international study. Review of Accounting; Finance, 6(1), 86-101.

Djama, C., Dumas, G., \& Martinez, I. (2014). Activité d'innovation et gestion des résultats comptables: une étude empirique sur le marché français. Finance Contrôle Stratégie, 17(2).

Donaldson, L. (1990). The Ethereal H: Organizational Economics and Management Theory. Academy of Management Review, 15(3), 369-381.

Eisenhardt, K. M. (1989). Agency theory: An assessment and review. Academy of Management Review, 14, 57-75.

Elouadi, D., Ben Noamene, M. T., \& Chaher, D. (2016). Employee Ownership And Employee - Shareholders Satisfaction: An Analysis Of French Companies Listed On The SBF 250. The Journal of Applied Business Research, 32(3), 981-994.

Finkelstein, S., \& Aveni, R. A. (1994). CEO Duality as a Double-Edged Sword: How Boards of Directors Balance 
Entrenchment Avoidance and Unity of Command. Academy of Management Journal, (5), 1079-1108.

Garvey, G. T., \& Swan, P. L. (1994). The Economics of Corporate Governance, Beyond the Marshallian Firm. Journal of Corporate Finance, (1), 139-174.

Guidara, R., \& Boujelbene, Y. (2014, April). Earnings Management around Research and Development Manipulation. International Journal of Academic Research in Accounting, Finance and Management Sciences, 4(2), 26-37.

Hall, B. H. (1998). Innovation and market value. NBER WP, $N^{\circ} 6984$.

Hansen, G. S., \& Hill, C. W. (1991). Are institutional investors myopic? A time series study of four technology driven industries. Strategic Management Journal, 12(1), 1-16.

Hermalin, B., \& Weisbach, M. (1988). The Determinant of Board Composition. Journal of Economics, (4), 589-606.

Hill, S., Martin, R., \& Harris, M. (2000). Decentralization, integration and the post-bureaucratic organization: The case of R\&D. Journal of Management Studies, 37(4), 563-586.

Hirshleifer, D. (1993). Managerial reputation and corporate investment decisions. Financial Management, 22(2), 145-160.

Hoskisson, R. E., Hitt, M. A., Johnson, R. A., \& Grossman, W. (2002). Conflicting voices: the effects of ownership heterogeneity and international governance on corporate strategy. Academy of Management Journal, 45(4), 697-716.

Jensen, M. C. (1993). The modern industrial reVol.ution, exit and the failure of internal control systems. Journal of Finance, 48(3), 831-881.

Jensen, M., \& Meckling, W. (1976). Theory of the firm: Managerial behaviour, agency costs and ownership structure. Journal of Financial Economics, 3(4), 305-360.

Katila, R. A., \& Ahuja, G. (2002). Something old, something new: A longitudinal study of search behaviour and new introduction. Academy of Management Journal, 45(6), 1183-1194.

Lee, H. U., \& Park, J. H. (2008). The influence of top management team international exposure on international alliance formation. Journal of Management Studies, 45(5), 961-981.

Lin, B. W., \& Chen, J. S. (2005). Corporate Technology Portfolios and R\&D Performance Measures: A Study of Technology Intensive Firms. $R \& D$ Management, 35(2), 157-170.

Lundstrum, L. L. (2002). Corporate investment myopia: A horserace of the theories. Journal of Corporate Finance, 8(4), 353-371.

Morck, R., Shleifer, A., \&Vishny, R. (1988). Management Ownership; Market Valuation: An Empirical Analysis. Journal of Financial Economics, 20(1-2), 293-315.

Nekhili, M., \&Poincelot, E. (2000). La fonction R\&D et la latitude managériale : Une analyse théorique. Finance Contrôle Stratégie, 3(1), 5-28.

Nickell, S., Nicolitsas, D., \& Dryden, N. (1997). What makes firms perform well?. European Economic Review, 41(3-5), 783-796.

Paquerot, M. (1996). Stratégies d'enracinement des dirigeants et prises de contrôle. Thèse de doctorat en sciences de gestion. Université de Bourgogne.

Paquerot, M. (1997). Stratégies d'enracinement des dirigeants, performance de la firme et structure de contrôle. In le gouvernement des entreprises, Charreaux, 1997, Economica, pp. 105-138.

Pfeffer, J. (1981). Power in Organizations. Harper Business.

Pichard-Stamford, J. P. (2000). Légitimité et enracinement du dirigeant par le réseau des administrateurs. Finance Contrôle Stratégie, (4), 143-178.

Pigé, B. (1998). Enracinement des dirigeants et richesse des actionnaires. Finance-Contrôle - Stratégie, 1(3), 131-158.

Pochet, C. (1998). Le Dirigeant et la Création de Valeur: les Facteurs de Contingence de la Latitude Managériale. Marchés et Organisations: Actes des XIVè journées des IAE. Nantes.

Rose, N. L., \& Shepard, A. (1997). Firm Diversification; CEO Compensation: Managerial Ability or Executive 
Entrenchment?. Journal of Economics, (3), 489-513.

Sallami, B. (2010). Gouvernement d'entreprise, investissement dans les activités de recherche et dévelopement et performance. Thèse de doctorat.

Shleifer, A., \& Vishny, R. W. (1986). Large shareholders and corporate control. Journal of Political Economy, 94(3), 461-488.

Shleifer, A., \& Vishny, R. W. (1989). Management Entrenchment: The case of manager specific investments. Journal of Financial Economics, 25(1), 123-139.

Shleifer, A., \& Vishny, R. W. (1990). Equilibrium short horizons of investors; firms. American Economic Review, $80(2), 148-153$.

Shleifer, A., \& Vishny, R. W. (1997). A survey of corporate governance. Journal of Finance, 52(2), 737-783.

Ume, S., \& Hussain, A. (2018). A Comparative Study on Corporate Diversification and Firm Performance across South Asian Countries. Journal of Accounting \& Marketing, 7(1).

Williamson, O. E. (1985). The economics of institutions of capitalism: Firms, markets and relational contracting. New York, MacMillan Free Press.

Williamson, O. E. (1988). Corporate finance and corporate governance. Journal of Finance, 43(3), 567-591.

Wiseman, R., \& Gomez-Mejia. (1997). Reframing executive compensation: an assessment and outlook. Journal of Management, 23, 291-374.

Yang, Y. W., Searcy, D. W. L., \& Tatum, K. W. (2007). The role of corporate governance on long-term financial performance and market valuation of $\mathrm{R} \& \mathrm{D}$ investments in the biotechnology industry. Working paper, Proceedings of the Midyear Conference of the, Auditing Section of the American Accounting Association, January 11-13.

\section{Notes}

Note 1. Frascati Manual, OECD, 2002, p. 34. Available at: https://www.oecd ilibrary.org/docserver/9789264299047fr.pdf?expires=1532524971\&id=id\&accname=guest\&checksum=9EF164CB8 9D47DD11960E5AE1B0C85C5

Note 2. http://www.uis.unesco.org/template/pdf/S\&T/Workshops/Tunis/14.pdf

Note 3. The ISO 9000 standard 2000 version provides for a product design section which involves the implementation by the organization of an R \& D lab A list is available at the Agency for the Promotion of Industry and Innovation (APII).

\section{Copyrights}

Copyright for this article is retained by the author(s), with first publication rights granted to the journal.

This is an open-access article distributed under the terms and conditions of the Creative Commons Attribution license (http://creativecommons.org/licenses/by/4.0/). 